\title{
Constant volume balloons measurements in the urban Marseille and Fos- Berre industrial ozone plumes during ESCOMPTE experiment
}

\author{
Bruno Beénech ${ }^{\mathrm{a}}$, Agustin Ezcurra ${ }^{\mathrm{b}}$, Marie Lothon ${ }^{\mathrm{a}}$, Frédérique Saïd ${ }^{\mathrm{a}}$, Bernard Campistron ${ }^{\mathrm{a}}$, \\ Fabienne Lohou ${ }^{a}$, Pierre Durand ${ }^{\text {a }}$ \\ ${ }^{\text {a }}$ Laboratoire d'Aérologie, UMR 5560 CNRS/UPS, 31400 Toulouse, France \\ ${ }^{\mathrm{b}}$ Dpto. Fisica Aplicada 2, UPV-EHU, 01006 Vitoria, Alava, Spain
}

\begin{abstract}
ESCOMPTE programme aims at studying the emissions of primary pollutants in industrial and urban areas, their transport, diffusion and transformation in the atmosphere. This experiment, carried out in southeast France, can be used to validate and to improve meteorological and chemical mesoscale models. One major goal of this experiment was to follow the pollutant plumes, and to investigate its thermodynamic and physico-chemical time evolution. This was realized by means of constant volume balloons, located by global position satellite (GPS) and equipped with thermodynamic and ozone sensors, flying at constant density levels. During the two ESCOMPTE campaigns that took place in June and July 2000 and 2001, 40 balloons were launched, 17 of them equipped with ozone sensors during the day from 0800 to 1800 UTC. Balloons' altitudes flight levels ranged between 400 and $1200 \mathrm{~m}$ altitude with Mistral (northerly synoptic flow) and Sea Breeze (southerly breeze) conditions. The atmospheric boundary layer (ABL) topography of the experimental domain is complex and varies strongly from day to day. Its depth presents a large gradient from the sea coast to the north part of the ESCOMPTE domain, and also more complex variability within the domain. The balloons' trajectories describe the evolution of the pollutant plume emitted from the industrial area of Fos-Berre or from the Marseille urban area. Constant volume balloons give a good description of the trajectories of these two plumes. The balloons, which fly at an isopicnic level, cross different atmospheric layers chiefly depending on the $\mathrm{ABL}$ height in relation with the constant volume balloons flight level. Thus, each balloon flight is decomposed into different segments that correspond to the same atmospheric layer. In each segment, the ozone content variation is analyzed in relation to other thermodynamical parameters measured by the balloon and mainly to the vapor mixing ratio content. During ESCOMPTE campaign, the mean linear rate of chemical net ozone production at the top of the atmospheric boundary layer was found to be around $6 \mathrm{ppb} \mathrm{h}^{-1}$.
\end{abstract}

\section{Introduction}

The expanding industrialisation and rapidly growing mobility of the human society during the past 30 years are

\footnotetext{
* Corresponding author. Tel.: +34945014125.

E-mail address: agustin.ezcurra@ehu.es (A. Ezcurra).
}

producing an increase in tropospheric ozone concentration that has doubled in urban and peri-urban areas around the world (Volz and Kley, 1988). During the socalled summer smog episodes caused by high-pressure weather conditions, ozone concentration in the polluted continental boundary layer exhibits at the surface a pronounced diurnal cycle with a maximum during the day and a minimum at night. At night, ozone 
concentrations decrease in the shallow stable stratified surface layers because of dry deposition and chemical reactions, whereas ozone is conserved approximately in the layer aloft. In the morning, convection dissolves the nocturnal surface. During the day, turbulent mixing and photochemical activity are the main sources of ozone variability in the low layers of the troposphere. The nocturnal residual layer of the atmospheric boundary layer (ABL) acts as an ozone reservoir. Diurnal CBL growth plays an important role in the morning increase of surface ozone measurements as it has been analyzed for example by Baumbach and Vogth (2003).

Accumulated air pollution in the higher troposphere and even stratospheric ozone can also intrude into the lower atmospheric layers, where it is mixed down with ambient air by vertical turbulence, as pointed out by Davies and Schuepbach (1994); Millan et al. (1992, 1996); Ciccioli et al. (1987); Fortezza et al. (1993) and Georgiadis et al. (1994). In the other way, works by Rosenthal et al. (2003) and Hastie et al. (1999) show experimental evidence that fast transport of ozone up to the midtroposphere is linked to up-slope winds produced in mountains.

On the Mediterranean coastline, summer smog episodes often occur in link with sea breeze conditions. In those areas, large-scale circulation cells are established and coastal emissions can be trapped for several days in the land-sea breeze. The MEDCAPHOT-TRACE experimental field campaign (Ziomas et al., 1998) and the results from the MECAPIP (Millan et al., 1996) indicate that mesoscale circulations generated in the Mediterranean area play an important role in the formation of photooxidants over Spain and the Western Mediterranean. Photochemical oxidant episodes in the Mediterranean have been observed affecting the regions with major cities in particular, such as Barcelona, Marseille, Rome and Athens (Borrell et al., 1995). Case studies on these phenomena are reported for Athens, Valencia and Lisbon by Moussiopoulos (1994), Millan (1993) and Borrego et al. (1994).

Despite all experimental efforts carried out in order to determine local temporal change in ozone concentrations measured in the continental boundary layer, quantitative experimental-based understanding of ozone formation is still lacking.

Constant volume balloons instrumented with an ozone probe and launched during the ESCOMPTE campaign (Cros et al., 2004) bring new insight on the time evolution of the ozone content in the polluted low troposphere due to industrial and large urban sources located near the coast of the Mediterranean Sea. The constant volume balloons are appropriate tools to accurately follow air parcels trajectory and measure pollutant concentration.

The ESCOMPTE experimental programme is embedded in a long-term strategy aimed at improving air quality in the Marseille area (Cros et al., 2004). As shown in Fig. 1, the geography of the ESCOMPTE area is complex, with a jagged coastline running in a mostly northwest/southeast direction, and Berre pond adding to the shoreline complexity. The main ridges in the area are the Alpilles hills (altitude $300 \mathrm{~m}$ ) to the north of the Berre pond and the

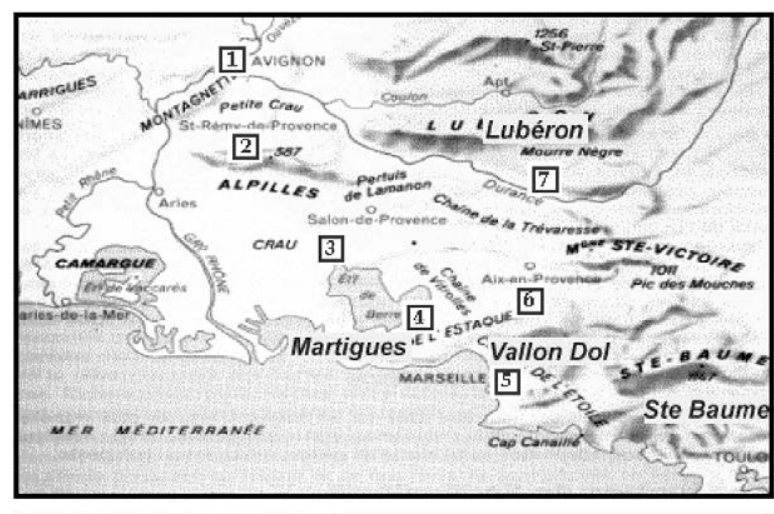

RADIOSOUNDING SITES

1- AVIGNON 2-ST. REMY 3-ST CHAMAS 4 MARIGNANE S- MARSEILLE 6.- AIXLE MILLES 7- AVIGNON

CVB LAUNCHING AND TRACKING STATIONS

MARTIGUES - VALLONDOL - STE BAUME - LUBERON

Fig. 1. Experimental ESCOMPTE area: radio sounding stations (1-7) are indicated, as well as the balloon release (Martigues and Vallon Dol) and tracking stations (Luberon and Saint Baume).

Sainte Baume mountain (altitude $1100 \mathrm{~m}$ ), Sainte Victoire mountain (altitude $1000 \mathrm{~m}$ ) and Luberon chain (altitude $1100 \mathrm{~m}$ ) to the east (quoted from south to north). The area is also dominated by the large valleys of two principal rivers: the Rhone (oriented $\mathrm{N}-\mathrm{S}$ ) and the Durance (oriented W-E).

One major aim of the constant volume balloon experiment during ESCOMPTE was to study the variation of ozone produced by the emissions of the urbanised area of the city of Marseille and the "Fos-Berre" industrial area and to investigate its thermodynamic and physico-chemical time evolution. The balloons used during ESCOMPTE were operated by the Centre National d'Etudes Spatiales (CNES) and instrumented by the Laboratoire d'Aérologie (LA) and Météo France (MF). Located by GPS and equipped with thermodynamic and ozone sensors, they were launched to fly at constant density levels (almost constant altitude) around the top of the ABL. Constant volume balloons have been extensively used as air mass tracers (Koffi et al., 2000). Truly isopycnic tracers, they are close to the Lagrangian tracers of the mean horizontal air flow and were largely used to describe the horizontal atmospheric motion in different experiments (orographic flow, coastal area, urban areas). It is the first time that constant volume balloons are instrumented with thermodynamic and ozone sensors to evaluate the time evolution of the ozone content near the top of the ABL.

Very few data exist that tell us about the time evolution of the ozone content along polluted areas. Generally, the measurements are made (i) at ground level with a network in which the continuity of the plume trajectories is not easily defined, (ii) using an aircraft, which gives only Eulerian ozone content along the flight track, or (iii) by vertical soundings in a single place.

The constant volume balloons bring new quasiLagrangian information that is very useful in the evaluation of net production/loss rates of the ozone content. 
For this, it is necessary to clearly identify the air masses crossed by the balloons. We present here our methodology to do so, based on the analysis of time variation of ozone in relation with vapor mixing ratio that is then used as a passive tracer to estimate the role of the dynamical turbulent transport.

\section{Experimental methodology}

The constant volume balloon is a super pressure balloon built with rigid material such that its volume is essentially constant with overpressure (excess internal pressure). Its mass is nearly constant for flight times that do not exceed $5-10 \mathrm{~h}$, since the loss of helium across the mylar envelop is insignificant at this time scale. Under such conditions, the balloons fly at a density level at which the weight of the air displaced is exactly equal to the weight of the balloon, helium and payload. If the balloon is displaced above (or below) its density level, it becomes negatively (positively) buoyant and seeks (rises) to return to its original level. These induced oscillations depend on the environmental atmospheric stability of the layer crossed by the balloon. If we exclude the gravity waves which appear in stable layers in the lee of the relief, the vertical oscillations of the balloon are generally due to vertical turbulent motions. In the ESCOMPTE experiment, the balloons could fly in the stable ABL early in the morning, close to the top of the boundary layer, or just in the free atmosphere above during the day in a stable layer $(\mathrm{SL})$, or in the neutral residual layer during the evening. In addition, with the other experimental means used during ESCOMPTE, like aircraft or radiosoundings, the ABL is well described spatially and temporally. The vertical oscillations of the balloons, temperature and humidity measurements are also indices of the atmospheric turbulence.

During ESCOMPTE, the balloons developed by the CNES consist of $2 \mathrm{~m}^{3}$ cylinders, of $7 \mathrm{~m}$ height and with a diameter of $0.6 \mathrm{~m}$, ended on each side by two hemispherical crowns (Fig. 2A). The envelope material is made with two layers, one of transparent mylar of $20 \mu \mathrm{m}$
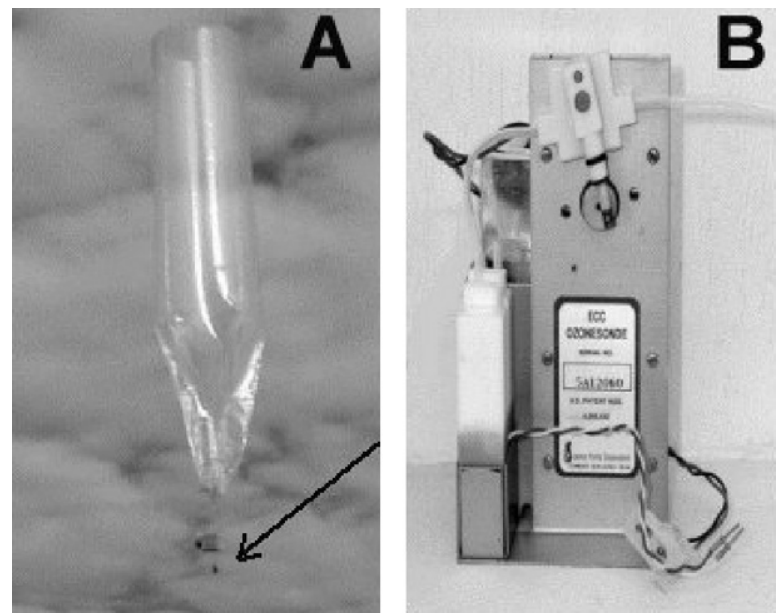

Fig. 2. (A) CVB rising with payload and (B) detail of a Vaisala ozone sensor. thickness and one of polyethylene film of $10 \mu \mathrm{m}$ thickness. Balloons are inflated with helium to obtain overpressures from 20 to $40 \mathrm{hPa}$ above the ambient pressure at their flight altitude. The payload is composed of: (i) a Vaisala radiosonde (RS80 GPS2) measuring pressure (accuracy $\pm 0.5 \mathrm{hPa})$, temperature $\left( \pm 0.2{ }^{\circ} \mathrm{C}\right)$, humidity $( \pm 2 \%)$; (ii) a GPS system giving the horizontal location of balloons and wind measurement (velocity accuracy $\pm 0.5 \mathrm{~ms}^{-1}$, direction accuracy $<5^{\circ}$ ); (iii) either an electrochemical concentration cell (ECC) ozone sensor (Fig. 2B) or an overpressure sensor, as well as a temperature sensor to control the internal pressure (precision $\pm 1 \mathrm{hPa}$ ) and temperature (precision $0.5^{\circ} \mathrm{C}$ ) of the helium gas. The accuracy of the observed CVB altitude estimated from an error calculation on the Laplace equation depends mainly on the accuracy of the pressure sensor. On average, an absolute error of $\pm 5 \mathrm{~m}$ is found.

The measurement principle of the VAISALA ECC ozone sonde is based on the electrochemical detection of ozone, which is sucked into an iodine/iodide solution. Performance evaluation of ECC ozone sonde was conducted for example by Beekman et al. (1995) through comparison with aircraft and LIDAR measurements and also in an environmental simulation chamber (Frejafon et al., 2002). The relative accuracy of the ECC sonde indicated by Beekman et al. (1995) is 3\%. But additional errors can occur during the flight due to a modification of the pump airflow, change in the temperature of the pump, evaporation of the solution and also the presence of gases such as $\mathrm{SO}_{2}$, which can modify the electrochemical reaction. Frejafon et al. (2002) show that there is a small dependence of the ozone content measurements made by ECC ozone probe on humidity: $<5 \%$ ozone concentration change was found for humidity changes from $25 \%$ to $80 \%$. This experiment, carried out in an environmental control chamber, clearly pointed out that the ECC sonde can be used to accurately measure the ozone content of the lower troposphere despite the strong change in humidity content which can occur, for example, across the interface between the ABL and the free troposphere.

The experimental design during the ESCOMPTE campaigns enabled us to release and track the constant volume balloons in order to follow the pollutant plumes emitted from the industrial area (FOS-BERRE) and from the urban area (MARSEILLE). The first release (and tracking) station, located in Martigues (AIRFOBEP area: $43^{\circ} 25^{\prime} 00^{\prime \prime} \mathrm{N}, 05^{\circ} 03^{\prime} 00^{\prime \prime} \mathrm{E}, 107 \mathrm{~m}$ altitude) north to the industrial area of Fos-Berre, was aimed at monitoring the industrial plume. The second release (and tracking) station located in Vallon Dol $\left(43^{\circ} 21^{\prime} 00^{\prime \prime} \mathrm{N}, 05^{\circ} 24^{\prime} 00^{\prime \prime} \mathrm{E}\right.$, $270 \mathrm{~m}$ altitude), north to Marseille, was well appropriate to monitor the urban plume during sea breeze cases. In addition to the two release stations, two other tracking stations were settled. One located at Mount Negre $\left(43^{\circ} 48^{\prime} 56^{\prime \prime} \mathrm{N}, 05^{\circ} 28^{\prime} 02^{\prime \prime} \mathrm{E}, 1125 \mathrm{~m}\right.$ altitude) in the LUBERON Mountains could follow the balloons flying along the Rhone and Durance valleys. The other was located at Ste Baume (43 $19^{\prime} 01^{\prime \prime} \mathrm{N}, 05^{\circ} 43^{\prime} 43^{\prime \prime} \mathrm{E}, 1033 \mathrm{~m}$ altitude) and allowed us to track the balloons flying above the Durance valley, chiefly to the south of the Sainte Victoire Mountain (Fig. 1). Those four tracking stations were needed for an 
accurate tracking of the balloons flying at low altitude due to the complex topography of the experimental domain.

Data measured by the constant volume balloons (pressure, temperature, humidity, GPS coordinates and ozone concentration or helium pressure and temperature) were sent to the ground stations. The wind was calculated by using the GPS differential mode. The balloon trajectory and associated parameters were calculated based on the combination of the data collected from the best signal obtained from the different ground stations.

The data set used in this paper is averaged over $5 \mathrm{~s}$. An example of one balloon flight data for the case of 25 June 2001 is presented in Fig. 3. The trajectory of the balloon CVB 13 launched from Vallon Dol is plotted, as well as the time evolution of altitude trajectory and ground relief under the trajectory (upper panel), temperature and vapor
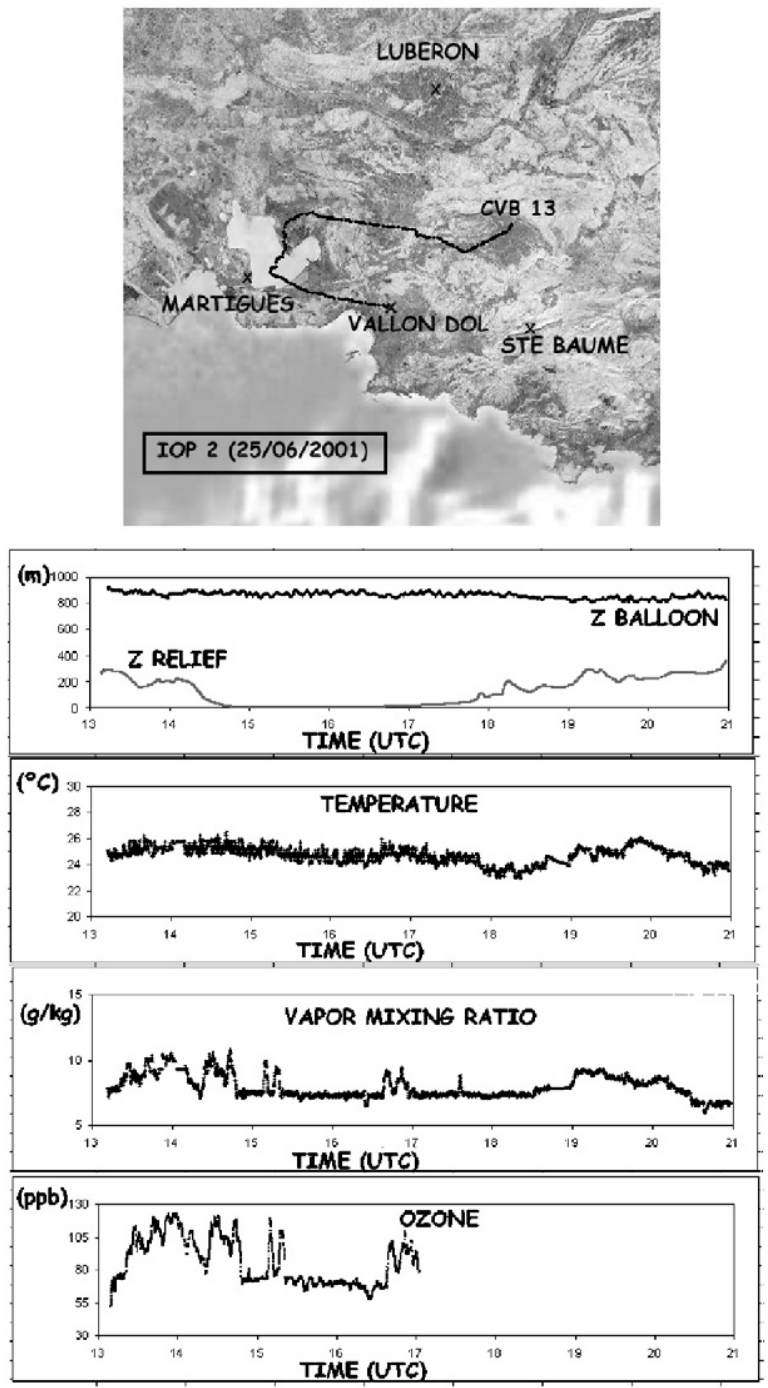

Fig. 3. Trajectory of CVB 13 launched from Vallon Dol during IOP 2 (25 June 2001). Temporal evolution of thermodynamic values and ozone concentration measured by CVB13 are also presented. Upper panel: altitude and ground relief; middle panel: potential temperature and vapor mixing ratio content; lower panel: ozone content. mixing ratio (middle panel) and ozone concentration (lower panel).

During ESCOMPTE campaign, we compared the balloon ozone data with the surface network ozone measurements and with aircraft measurements when the measurements were made almost at the same time and location. For example, Fig. 4A shows the ozone measurements made by the AIRMAREX surface network and those measured by the balloon CVB 13 at the same time and same location. The balloon takes off from Vallon Dol at 1300 UTC with an ozone content of 60 ppb. Between 1330 and 1500 UTC, the constant volume balloon flies at $800 \mathrm{~m}$ height, with a north west direction, near the ABL top with an ozone content of $100-120 \mathrm{ppb}$, larger than what was observed at the ground. From 1500 to 1700 UTC, the balloon flies just above the ABL top over the Berre pound, and nearly the same content (about $60 \mathrm{ppb}$ ) is observed at the ground and at the balloon flight level. After 1700 UTC, the ozone content increases again to reach about $90 \mathrm{ppb}$, when the balloon turns eastward and enters into the ABL again. The same day, the Fokker 27 aircraft was flying at nearly the same altitude and time $(875 \mathrm{~m}$ high between 1100 and 1205 UTC) as the balloon. The aircraft measurements give low concentration of ozone content above the Berre pond (about $75 \mathrm{ppb}$ ) and high concentration of ozone in the east part of the area (about 80-120 ppb) (Fig. 4B) (Saïd et al., 2007; Kalthoff et al., 2005). Similar values were also recorded by the CVB 13 balloon. During
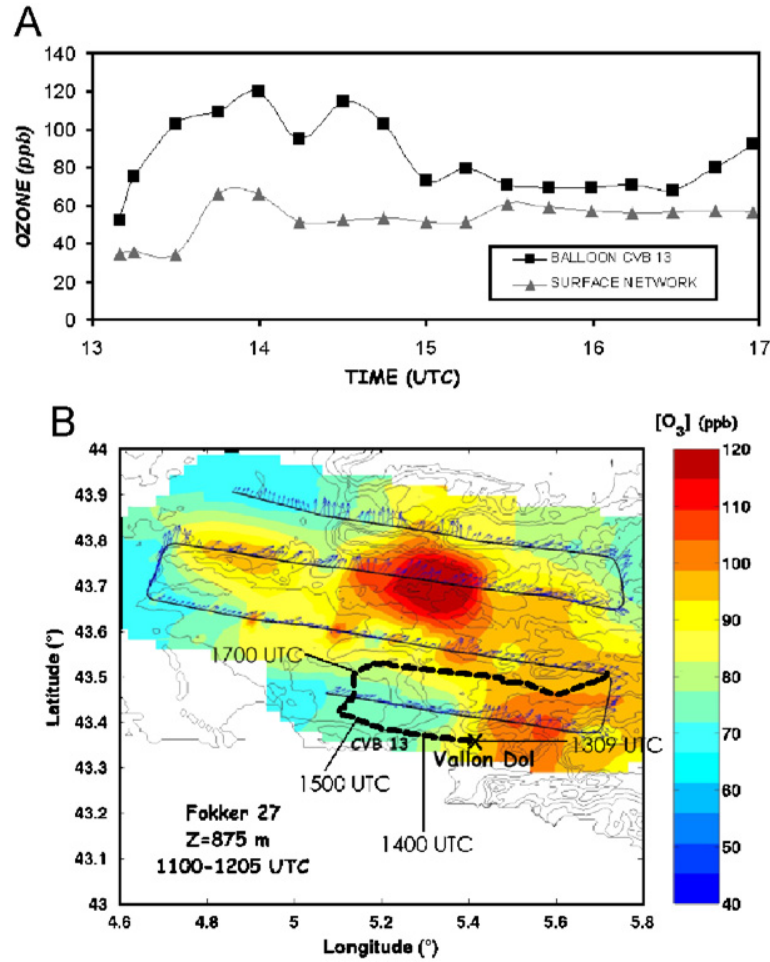

Fig. 4. (A) Ozone content along the CVB track of CVB 13 and at surface. The surface ozone content just under the balloon trajectory is determined by the interpolation of the three nearest ground AIRMAREX stations. (B) Ozone concentration field deduced from aircraft measurements during IOP 2 (25 June 2001) and CVB 13 trajectory. 
this day, we have nearly the same values and the same tendency between aircraft data (1100-1205 UTC) and the first part of the balloon data (1300-1500 UTC). The ozone contents measured by balloon at ground level are similar to ozone content measured by the ground network, and large difference of ozone content is observed between the ground and the ABL top as seen by the aircraft and constant volume balloon.

\section{Results}

\subsection{Constant volume balloons trajectories overview}

During ESCOMPTE, two main atmospheric situations have been extensively investigated: the case of Mistral, which is a strong north wind with relatively low ozone content and the case of sea breeze with high ozone content in the ESCOMPTE domain (Saïd et al., 2007).

Westerly to northerly upper-level large-scale flow patterns may lead to Mistral events. They are usually associated with a Genoa Gulf cyclone in the lee of the Alps and a high-pressure system in North West Europe that produces a north-south negative pressure gradient component at ground level allowing the air masses to be channelled and accelerated within the Rhone valley. Surface winds usually range from 10 to $20 \mathrm{~m} \mathrm{~s}^{-1}$ over land, but situations leading to offshore winds reaching $30-40 \mathrm{~m} \mathrm{~s}^{-1}$ are frequent. Mistral is a low-level jet which can strongly affect the ABL-dynamics (Guénard et al., 2005).

During summer and under anticyclonic conditions with low synoptic wind, the daily mesoscale flow is driven by the sea breeze winds. In such cases, ozone content shows high values, which can make pollution peaks, especially to the north of the ESCOMPTE domain (Drobinski et al., 2005).

A preliminary campaign (summer 2000) was conducted from 19 June to 9 July 2000. The period of the ESCOMPTE campaign 2001, from 4 June to 14 July, was particularly favourable to the pollution event, with no less than 11 days affected by strong atmospheric pollution. Table 1 presents the intensive observation period (IOP) number for each balloon, the CVB balloon number related to the yearly campaign and the main characteristics of the flights, together with the direction of the synoptic flow, launching station, launching time, flight duration, covered distance, flight altitude, trajectory direction and mean balloon speed. The type of the additional sensor $\left(\mathrm{O}_{3}\right.$ : ozone sensor, $\mathrm{d} P / \mathrm{dTi}$ : internal pressure of balloon and temperature) is also added.

During ESCOMPTE 2000 and 2001, a total of 40 balloons were released during 6 IOP in order to explore the evolution of the airmass thermodynamic. Seventeen balloons were equipped with ozone sensors and reported the time variation of the ozone content along the balloon trajectory for only $3-6 \mathrm{~h}$. The other balloons were equipped with measurement of internal temperature and super pressure for accurate reporting of balloon dynamics (Koffi et al., 2000). This aspect will not be presented here.
As expected, the trajectories followed by the balloons according to the type of atmospheric situation mentioned above are quite different. During the day, in the sea breeze cases, the balloon travels inland, pushed by the sea breeze airflow. Throughout the day, the balloons' trajectories move in a clockwise direction. During the early morning the sea breeze pushes the balloons in the direction of the Rhone valley, but in late afternoon the trajectories are usually directed to the Durance valley as shown in Fig. 5A, corresponding to the sea breeze scenario on 25 and 26 June 2001 of the IOP 2A. In the opposite case, during Mistral events, the balloons are driven offshore as shown in Fig. 5B for the Mistral cases of 12 and 13 July 2001 of the IOP 4. In such cases, the balloon veers to the East, flying parallel to the coast in the general flow and splitting around the Alps.

\subsection{Constant volume balloon ozone measurements}

In order to perform the study of the ozone time evolution along the balloon trajectory, every measurement set obtained by one particular balloon requires a careful analysis. For each balloon flight, the balloon data have to be analyzed in relation to the ozone and thermodynamic parameters in order to identify the temporal segments in which the balloon flies in the same atmospheric layer. For this it is necessary to know the spatial and temporal evolution of $\mathrm{ABL}$ depth as it is referred for example by Stull (1993).

During ESCOMPTE, the spatial and temporal evolution of the ABL is well described by the radio soundings, the wind profilers and the aircraft measurements, which have been compared to a numerical simulation with MesoNH model. Some examples of the ABL spatial evolutions at 1400 UTC, deduced by Saïd et al. (2007), are presented for 3 days representative of the meteorological conditions encountered during the campaign (Fig. 6): 22 June corresponds to the end of a Mistral case, 24 June corresponds to a Westerly flow and 25 June 2001 corresponds to a sea breeze case. For the Mistral case (22 June), the ABL top is high over the area but remains low along the coastline where the balloon flies (Fig. 6A). For the sea breeze (25 June) and westerly flow (24 June) cases, the analysis conducted by Saïd et al. (2007) clearly points out that the height of the $\mathrm{ABL}$ is generally low above the Berre pond and the sea coastline, and increases with the distance from the sea (Fig. 6B and C). Over the relief, the $\mathrm{ABL}$ top can reach $1500 \mathrm{~m}$.

MesoNH simulations are in agreement with radiosounding measurements. Table 2 presents the ABL top heights $(\mathrm{Zi})$ deduced from the soundings carried out in the ESCOMPTE area during midday on 25 and 26 June corresponding to two sea breeze cases. A strong increase of $\mathrm{Zi}$ heights from the south to the north and from the southwest to the northeast is also observed. For 25 June, near the sea and Berre pond, $\mathrm{Zi}$ reaches $500-650 \mathrm{~m}$ (Marignane station, St. Chamas and Marseille). To the north (Avignon and St. Remy stations), Zi reaches $1000 \mathrm{~m}$. $\mathrm{Zi}$ increases steadily along the SW-NE axis from Aix les 
Table 1

Characteristics of the CVB flights during ESCOMPTE

\begin{tabular}{|c|c|c|c|c|c|c|c|c|c|c|c|}
\hline IOP & CVB-N/Y & Date & SFD & $\mathrm{LS}^{\mathrm{a}}$ & LT (UTC) & $\mathrm{FD}(\mathrm{HHmm})$ & $\mathrm{CD}(\mathrm{km})$ & $\mathrm{FA}(\mathrm{m})$ & TD & $\operatorname{MCVBS}\left(\mathrm{m} \mathrm{s}^{-1}\right)$ & AS \\
\hline 0 & $1 / 00$ & $29 / 06 / 00$ & $\mathrm{~N}$ & VD & 1209 & 0308 & 106 & $500 / 1800$ & SE & $10 / 9$ & $\mathrm{~d} P / \mathrm{Ti}$ \\
\hline 0 & $2 / 00$ & $30 / 06 / 00$ & W & M & 0533 & 0456 & 116 & 350 & SE/ESE & $6 / 8$ & $\mathrm{~d} P / \mathrm{Ti}$ \\
\hline 0 & $3 / 00$ & $30 / 06 / 00$ & W & M & 1224 & 0638 & 109 & 750 & ESE & 5 & $\mathrm{O} 3$ \\
\hline 0 & $4 / 00$ & $30 / 06 / 00$ & W & VD & 1519 & 0626 & 145 & 750 & $\mathrm{E} / \mathrm{ESE}$ & $10-5$ & $\mathrm{~d} P / \mathrm{Ti}$ \\
\hline 0 & $5 / 00$ & $01 / 07 / 00$ & $\mathrm{~S}$ & VD & 0454 & 0500 & 46 & 400 & NW & $2 / 6$ & $\mathrm{~d} P / \mathrm{Ti}$ \\
\hline 0 & $6 / 00$ & $01 / 07 / 00$ & $\mathrm{~S}$ & $\mathrm{M}$ & 0918 & 0521 & 135 & 800 & $\mathrm{~N}$ & $5-10$ & $\mathrm{O} 3$ \\
\hline 0 & $7 / 00$ & $01 / 07 / 00$ & $\mathrm{~S}$ & M & 1238 & 0400 & 89 & 600 & $\mathrm{~N} / \mathrm{NNE}$ & $10 / 5$ & $\mathrm{~d} P / \mathrm{Ti}$ \\
\hline 1 & $1 / 01$ & $14 / 06 / 01$ & W & M & 1323 & 0422 & 84 & 1000 & ESE & 5 & $\mathrm{~d} P / \mathrm{Ti}$ \\
\hline 1 & $2 / 01$ & $15 / 06 / 01$ & SW & M & 0659 & 0125 & 42 & 700 & NW & 9 & $\mathrm{O} 3$ \\
\hline $2 \mathrm{~A}$ & $3 / 01$ & $21 / 06 / 01$ & $\mathrm{~N}$ & $\mathrm{M}$ & 1425 & 0535 & 180 & 600 & ESE & 9 & $\mathrm{O} 3$ \\
\hline $2 \mathrm{~A}$ & $4 / 01$ & $22 / 06 / 01$ & $\mathrm{~N}$ & $\mathrm{M}$ & 0512 & 0020 & 04 & 130 & S & 4 & $\mathrm{~d} P / \mathrm{Ti}$ \\
\hline $2 \mathrm{~A}$ & $5 / 01$ & $22 / 06 / 01$ & $\mathrm{~N}$ & $\mathrm{M}$ & 0920 & 0146 & 70 & 600 & SE & $10-14$ & $\mathrm{O} 3$ \\
\hline $2 \mathrm{~A}$ & $6 / 01$ & $22 / 06 / 01$ & $\mathrm{~N}$ & $\mathrm{M}$ & 1557 & - & - & 800 & - & - & - \\
\hline $2 \mathrm{~A}$ & $7 / 01$ & $23 / 06 / 01$ & $\mathrm{~N}$ & VD & 0820 & 0231 & 104 & 800 & SSE & 10 & $\mathrm{~d} P / \mathrm{Ti}$ \\
\hline $2 \mathrm{~A}$ & $8 / 01$ & $23 / 06 / 01$ & $\mathrm{~W} / \mathrm{NW}$ & VD & 1248 & 0038 & 18 & 730 & ESE & $10-7$ & $\mathrm{~d} P / \mathrm{Ti}$ \\
\hline $2 B$ & $9 / 01$ & $24 / 06 / 01$ & W & $\mathrm{M}$ & 1107 & 1823 & $>200$ & 600 & ENE & 5 & $\mathrm{O} 3$ \\
\hline $2 B$ & $10 / 01$ & $24 / 06 / 01$ & W & $\mathrm{M}$ & 1402 & 0128 & 15 & 1550 & $\mathrm{E}$ & 4 & $\mathrm{~d} P / \mathrm{Ti}$ \\
\hline $2 B$ & $11 / 01$ & $25 / 06 / 01$ & SW & M & 0536 & 0609 & 68 & 500 & $\mathrm{~N}$ & $3 / 5$ & $\mathrm{~d} P / \mathrm{Ti}$ \\
\hline $2 B$ & $12 / 01$ & $25 / 06 / 01$ & SW & $\mathrm{M}$ & 0855 & 1040 & 79 & 650 & ENE/NNE & $3 / 5$ & $\mathrm{O} 3$ \\
\hline $2 B$ & $13 / 01$ & $25 / 06 / 01$ & SW & VD & 1309 & 0749 & 70 & 900 & $\mathrm{~W} / \mathrm{N} / \mathrm{E}$ & $4 / 5$ & $\mathrm{O} 3$ \\
\hline $2 B$ & $14 / 01$ & $26 / 06 / 01$ & SE & VD & 0458 & 1025 & 76 & 800 & $\mathrm{NE}$ & $3 / 5$ & $\mathrm{~d} P / \mathrm{Ti}$ \\
\hline $2 B$ & $15 / 01$ & $26 / 06 / 01$ & SE & VD & 0823 & 0436 & 86 & 850 & NW & 5 & $\mathrm{O} 3$ \\
\hline $2 B$ & $16 / 01$ & $26 / 06 / 01$ & SE & VD & 1317 & 0013 & 02 & 960 & WNW & 4 & $\mathrm{~d} P / \mathrm{Ti}$ \\
\hline $2 B$ & $17 / 01$ & $26 / 06 / 01$ & SE & VD & 1405 & 0700 & 120 & 1150 & NNW & $4-9$ & $\mathrm{~d} P / \mathrm{Ti}$ \\
\hline 3 & $18 / 01$ & $02 / 07 / 01$ & SW & $\mathrm{M}$ & 1308 & 0425 & 86 & 700 & ENE & $4 / 8$ & $\mathrm{~d} P / \mathrm{Ti}$ \\
\hline 3 & $19 / 01$ & $03 / 07 / 01$ & SE & M & 0457 & 0646 & 65 & 400 & $\mathrm{NW} / \mathrm{NE}$ & $2 / 5$ & $\mathrm{~d} P / \mathrm{Ti}$ \\
\hline 3 & $20 / 01$ & 03/07/01 & SE & M & 0850 & 0330 & 60 & 630 & $\mathrm{NE}$ & $4-7$ & $\mathrm{~d} P / \mathrm{Ti}$ \\
\hline 3 & $21 / 01$ & 03/07/01 & SE & $\mathrm{M}$ & 1513 & 0140 & 35 & 600 & ENE & $5 / 6$ & $\mathrm{O} 3$ \\
\hline 3 & $22 / 01$ & $04 / 07 / 01$ & $S$ & VD & 0736 & 0256 & 62 & 650 & NNE & $5 / 6$ & $\mathrm{~d} P / \mathrm{Ti}$ \\
\hline 3 & 23/01 & 04/07/01 & $\mathrm{S}$ & VD & 0938 & 0256 & 52 & 600 & NNE & $8-4$ & $\mathrm{O} 3$ \\
\hline 3 & $24 / 01$ & $04 / 07 / 01$ & $\mathrm{~S}$ & VD & 1256 & 0241 & 83 & 700 & $\mathrm{~N}$ & $9-11$ & $\mathrm{O} 3$ \\
\hline 4 & $25 / 01$ & $10 / 07 / 01$ & W/SW & M & 1412 & 0656 & 120 & 800 & $\mathrm{E} / \mathrm{NN} / \mathrm{E}$ & $8-4$ & $\mathrm{O} 3$ \\
\hline 4 & $26 / 01$ & $11 / 07 / 01$ & $\mathrm{~N}$ & M & 1007 & 0441 & 176 & 700 & SE/ESE & $20-15$ & $\mathrm{O} 3$ \\
\hline 4 & $27 / 01$ & $11 / 07 / 01$ & $\mathrm{~N}$ & M & 1350 & 0340 & - & 800 & - & - & $\mathrm{d} P / \mathrm{Ti}$ \\
\hline 4 & $28 / 01$ & $12 / 07 / 01$ & $\mathrm{~N}$ & M & 0455 & 0233 & 140 & 400 & SE & $18-16$ & $\mathrm{~d} P / \mathrm{Ti}$ \\
\hline 4 & $29 / 01$ & $12 / 07 / 01$ & $\mathrm{~N}$ & $\mathrm{M}$ & 0904 & 0231 & 101 & 650 & SE & 18 & $\mathrm{O} 3$ \\
\hline 4 & $30 / 01$ & $12 / 07 / 01$ & $\mathrm{~N}$ & M & 1254 & 0343 & 127 & 800 & SE & $19-16$ & $\mathrm{~d} P / \mathrm{Ti}$ \\
\hline 4 & $31 / 01$ & $13 / 07 / 01$ & $\mathrm{~N}$ & VD & 0715 & 0411 & 109 & 600 & SE/ESE & $19-15$ & $\mathrm{~d} P / \mathrm{Ti}$ \\
\hline 4 & $32 / 01$ & $13 / 07 / 01$ & $\mathrm{~N}$ & VD & 1000 & 0430 & 135 & 800 & $\mathrm{SE} / \mathrm{E} / \mathrm{NE}$ & $19-12$ & $\mathrm{O} 3$ \\
\hline 4 & $33 / 01$ & $13 / 07 / 01$ & $\mathrm{~N}$ & VD & 1310 & 0113 & 20 & 900 & $\mathrm{E}$ & 15 & $\mathrm{O} 3$ \\
\hline
\end{tabular}

IOP number (IOP), CVB number related to the campaign year (CVB-N/Y), date (DATE), mean synoptic flow (SFD), launching station (LS), launching time (LT), flight duration (FD), covered distance (CD) expressed in km, flight altitude (FA) in m, CVB trajectory direction (TD), CVB mean horizontal velocity (MCVBS) in $\mathrm{m} \mathrm{s}^{-1}$ and additional sensor (AS) to the Vaisala radiosonde (O3: ozone sensor, $\mathrm{d} P / \mathrm{Ti}$ : CVB internal pressure and temperature).

a M: Martigues or VD: Vallon Dol.

Milles $(\mathrm{Zi}=900 \mathrm{~m})$ to Vignon $(\mathrm{Zi}=1500 \mathrm{~m})$. The same trend is found on 26 June.

For each balloon, the flight altitude has been compared with the ABL top deduced from experimental means and MesoNH simulations. The vertical fluctuations of the balloons' heights, thermodynamical parameters and ozone content measured along the trajectories are also used as "turbulence" clues. The balloons fly at different levels ranging from 600 to $1000 \mathrm{~m}$ and can cross back and forth the ABL top, thus probing the free atmosphere or the $\mathrm{ABL}$ alternatively, depending on the spatial structure of the ABL.
As an example of determination of atmospheric layers crossed by one balloon, Fig. 7 represents the time evolution of altitude, vapor mixing ratio and ozone contents observed from the data measured by the balloon CVB 15, launched from Vallon Dol during the sea breeze case on 26 June 2001 . The balloon flies at $850 \mathrm{~m}$ height and takes a north-northwest direction, crosses the east side of Berre pound and then flies toward Avignon (Fig. 5A). In relation with the ABL top analysis, the balloon launched at 0825 UTC flies in three different atmospheric layers. During the first phase of the flight (0900-0950 UTC), temperature and water content remain still almost 


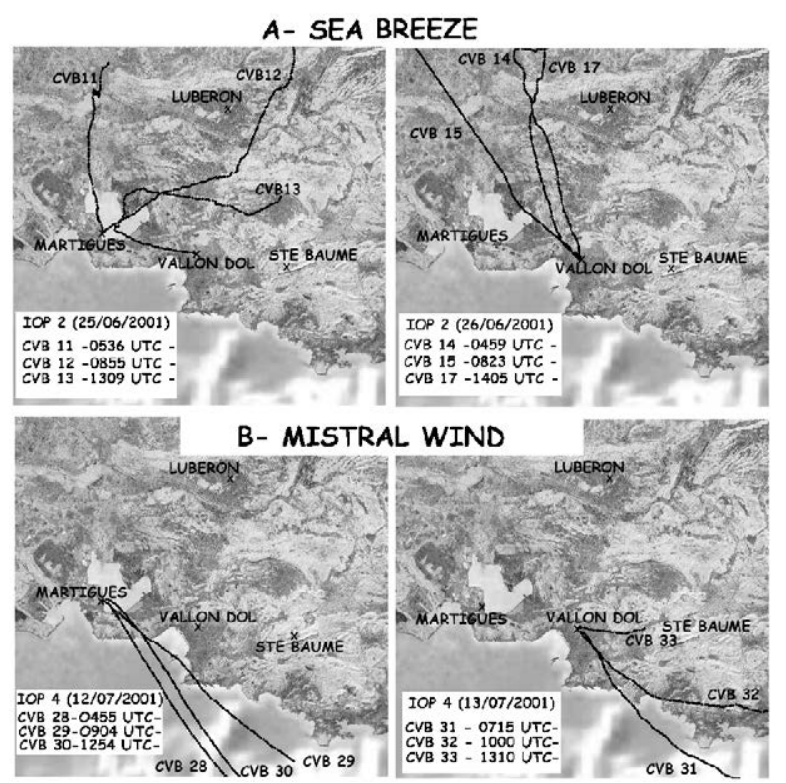

Fig. 5. Examples of trajectories followed by balloons during: (A) sea breeze cases of 25 and 26 June 2001 and (B) MISTRAL wind cases of 12 and 13 July 2001.

constant, with an instantaneous small increase of humidity content. Low oscillations of balloon vertical altitude and constant value of the ozone content are also observed. The balloon flies in the atmospheric stable layer, just above the inversion level (the ABL top is given to $750 \mathrm{~m}$ at Marseille (Table 2).

In the second phase (0950-1055 UTC), the water vapor content slightly increases, and temperature, altitude and ozone content remain almost constant over time. During this phase, the balloon flies along the north of the Berre pond within the atmospheric SL above the ABL as it can be deduced from radio sounding measurements made in Marignane (Table 2). Finally, in the third phase of the flight, ozone content, water content and temperature increase rapidly with time with a large variability. The ABL height at Avignon and Saint Remy reach $1000 \mathrm{~m}$. The balloon flies into a turbulent and convective ABL with strong up- and down-drafts.

This analysis has been applied on each balloon's flight. In this paper, only two types of atmospheric layers were considered: the $\mathrm{ABL}$ and the free atmosphere (SL layer above $\mathrm{ABL}$ ). Transition zones, IBL and nocturnal stable regions were excluded from our analysis.

For each trajectory segment representative of one atmospheric layer, the time evolution of the ozone $\left(\mathrm{dO}_{3} / \mathrm{d} t\right)$ was directly calculated from a linear regression of the ozone temporal evolution. Two examples are presented in Fig. 8 for balloons CVB 3 and 6 during the 2000 ESCOMPTE campaign. In the case of balloon CVB 3, the rate of ozone time variation calculated by linear regression from 1225 to $1420 \mathrm{UTC}$ is $13 \mathrm{ppbh}^{-1}$ with a linear regression coefficient of 0.98 . For the balloon CVB 6 , this rate is $3 \mathrm{ppb} \mathrm{h}^{-1}$ between 1030 and 1410 UTC with a linear regression coefficient of 0.97 . In both cases, these
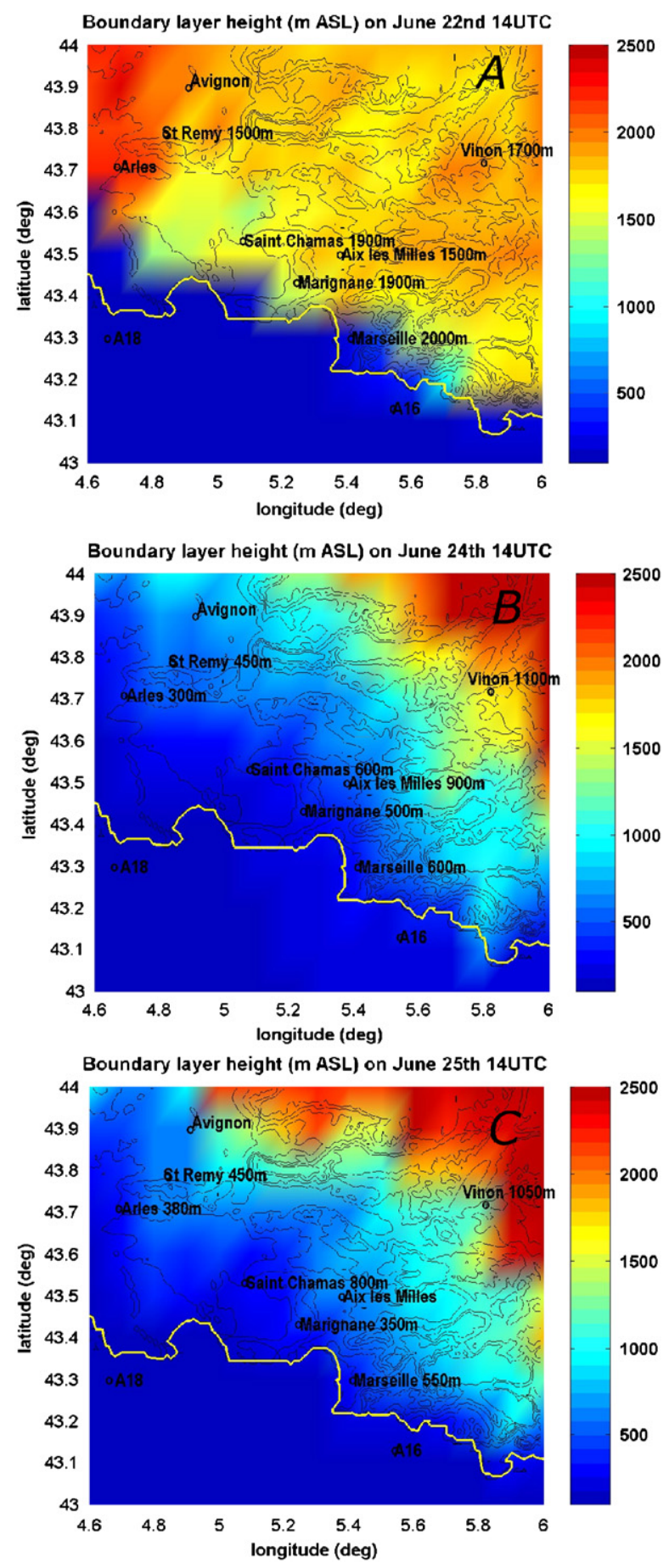

Fig. 6. MesoNH results of $\mathrm{ABL}$ top $\mathrm{Zi}$ (in $\mathrm{m} \mathrm{ASL}$ ) at $1400 \mathrm{UTC}$ in three cases: a Mistral episode (22 June 2001), a westerly flow (24 June 2001) and sea breeze (25 June 2001).

rates represent the mean trend of the ozone content in the atmospheric layer crossed by the balloons.

The linear trend in ozone temporal evolution can be interpreted as the quasi-Lagrangian variation produced inside of one individual air parcel driven by the air flow 
Table 2

Atmospheric boundary layer top (Zi) (m ASL) deduced from all radio soundings made over 25 and 26 June in the ESCOMPTE domain

\begin{tabular}{|c|c|c|c|c|}
\hline Sounding location & Longitude & Latitude & $\mathrm{Zi}(\mathrm{m})-25 / 06$ & $\mathrm{Zi}(\mathrm{m})-26 / 06$ \\
\hline 1-Avignon & 4.80 & 43.93 & 1000 & 1000 \\
\hline 2-St Remy & 4.83 & 43.79 & 450 & 1000 \\
\hline 3-St Chamas & 5.06 & 43.53 & 800 & 350 \\
\hline 4-Marignane & 5.23 & 43.43 & 350 & 500 \\
\hline 5-Marseille- Observatory & 5.40 & 43.30 & 550 & 750 \\
\hline 6_-Aix les Milles & 5.36 & 43.50 & 900 & 1250 \\
\hline 7-Vignon & 5.81 & 43.72 & 1050 & 1700 \\
\hline
\end{tabular}

For every station, latitude and longitude are also indicated.
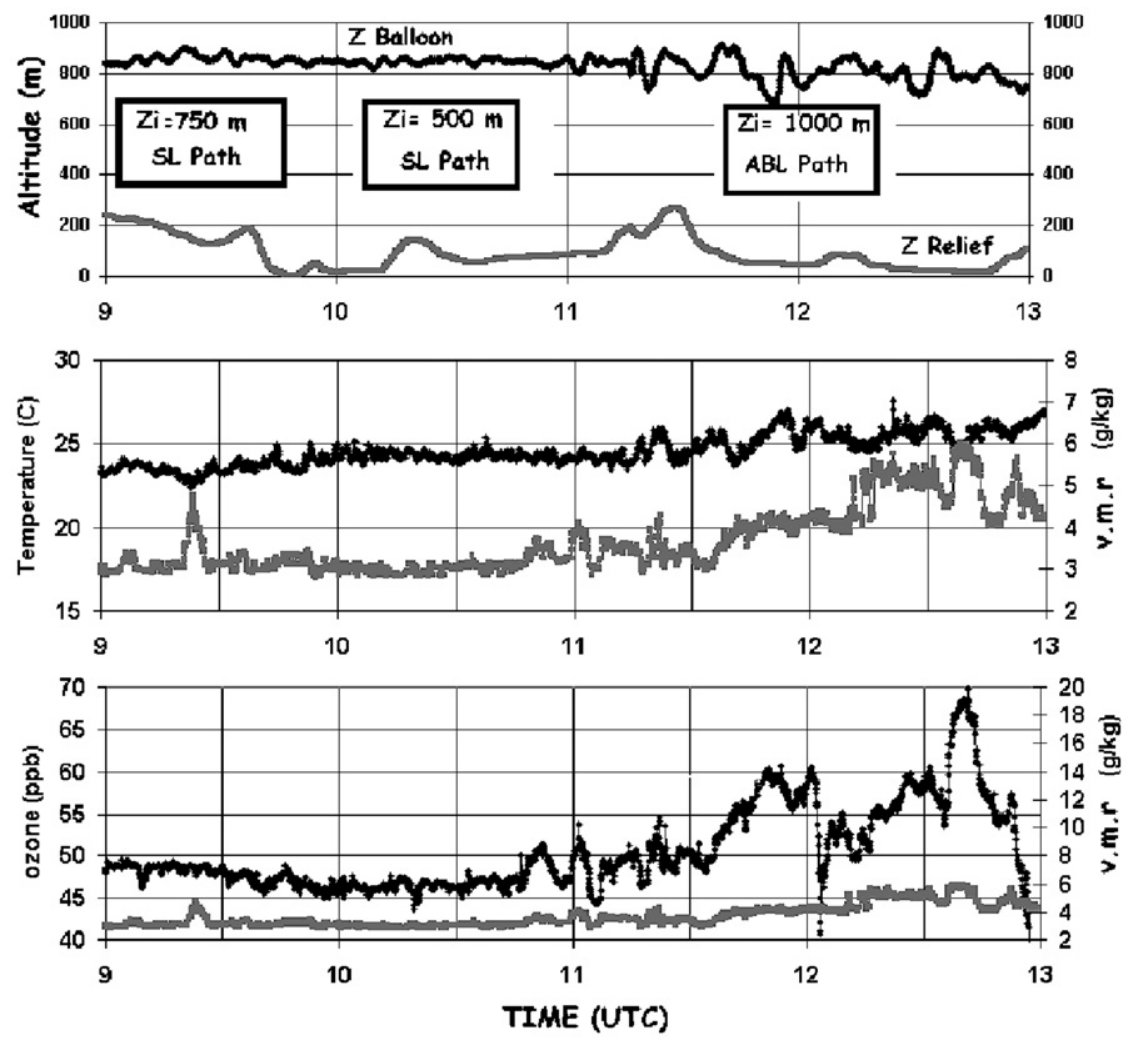

Fig. 7. Example of layer classification (ABL or stable SL-above ABL) for CVB 15 (26 June 2001) based on thermodynamic parameters, ozone content analysis and $\mathrm{ABL}$ top $\mathrm{Zi}$.

and only influenced by (i) the local chemical reaction and (ii) the vertical turbulent transport. To identify for each segment the principal contribution to the ozone variation, the time evolution of water ratio content as a tracer of turbulent transport into the $\mathrm{ABL}$ can be used. The Lagrangian time evolution of the water vapor content in a dry $\mathrm{ABL}$ is mainly linked with the latent heat fluxes at the ground or the exchange of humidity in the entrainment layer between $\mathrm{ABL}$ and the free atmosphere. Therefore, $\mathrm{d} q / \mathrm{d} t$ represents the increase or decrease of water vapor content due to vertical transport. For that reason, the influence of vertical turbulent transport on ozone variation can be estimated from the analysis of the correlation between water and ozone contents. As a first guess, if both contents (water vapor and ozone) are well correlated, the turbulent transport can be assumed to play an important role in the ozone variability.

Table 3 summarizes the different characteristics of the 28 flight paths studied in this paper: IOP number, date, flight time, release station, flight altitude, the atmospheric layer crossed by the balloon, the ozone content variation along the segment, its linear time variation and its linear correlation coefficient $\left(r_{\mathrm{O}_{3}}\right)$, the coefficient of linear correlation between the vapor mixing ratio trend and the ozone concentration trend $\left(R_{\mathrm{O}_{3} / \mathrm{H}_{2} \mathrm{O}}\right)$, the linear water vapor mixing ratio time variation and its linear correlation coefficient $\left(r_{\mathrm{H}_{2} \mathrm{O}}\right)$. The meteorological situation is also indicated. In 22 cases, a poor absolute correlation 

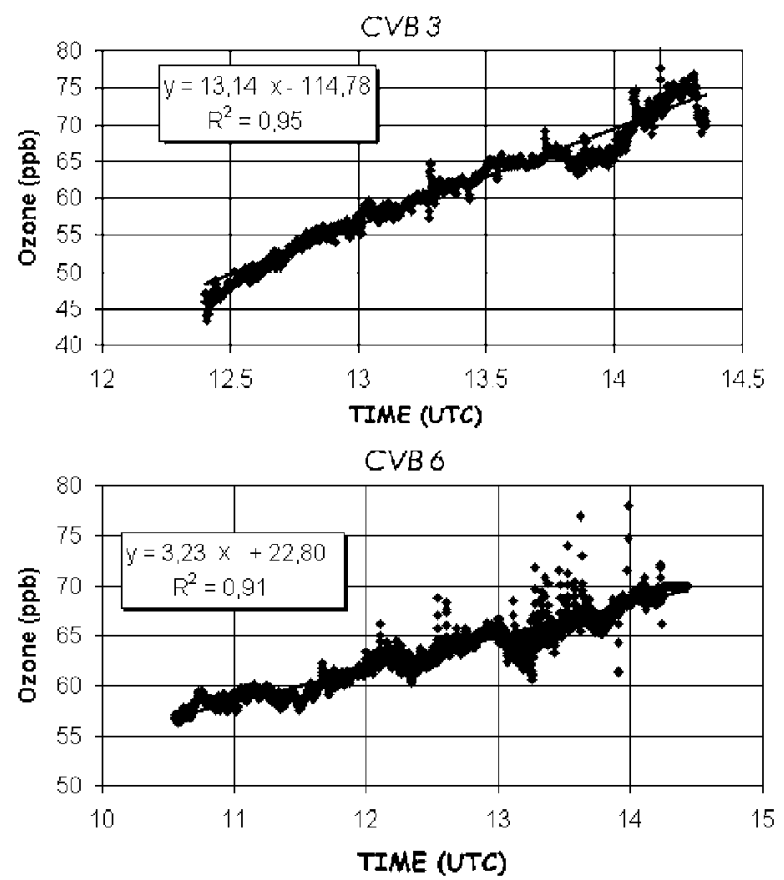

Fig. 8. Ozone concentration versus time for CVB 3 (30 June 2000) and CVB 6 (1 July 2000) of IOP 0. Ozone mean linear trend is shown with the value of the linear regression coefficient.

coefficient $R_{\mathrm{O}_{3} / \mathrm{H}_{2} \mathrm{O}}(<0.5)$ between vapor mixing ratio content and ozone content is found. In these cases, the temporal variation of ozone is not linked to the humidity content variation. The vertical ozone transport cannot explain the increase/decrease of the ozone content but only chemical reaction in relation to the primary pollutants present at the balloon flight level. Only in six cases do we find a significant correlation coefficient $R_{\mathrm{O}_{3} / \mathrm{H}_{2} \mathrm{O}}$ $(\geqslant 0.5)$. In two cases among them, no clear trend is found for vapor mixing ratio content $\left(r_{\mathrm{H}_{2} \mathrm{O}}\right.$ is weak) and the turbulent transport contribution is possible and not well defined. In the other four cases listed below, a clear trend of vapor mixing ratio content is found $\left(r_{\mathrm{H}_{2} \mathrm{O}}\right.$ is strong), suggesting that ozone temporal variation can be affected by turbulent transport and by chemical process.

(a) Case number 4 (IOP1) corresponds to a balloon launched in the morning (0700 UTC) from Martigues and gives $r_{\mathrm{O}_{3}}=0.9$ and $r_{\mathrm{H}_{2} \mathrm{O}}=0.5$. The turbulent transport, as indicated by the linear trend of vapor mixing ratio, represents about $12 \%$ per hour of positive change of the water vapor content. For ozone, we find a negative temporal variation close to $40 \%$. Therefore, in this case, the dynamical effect can explain part of the ozone variation (if ozone is provided by a layer where the ozone content is lower that the ozone content at the flight level) but the chemical destruction must also be very important.

(b) Case number 22 (IOP 4) corresponds to a balloon that was launched from Martigues in the ABL at $800 \mathrm{~m}$ under a westerly flow. In this segment, $r_{\mathrm{O}_{3}}, r_{\mathrm{H}_{2} \mathrm{O}}$ and $R_{\mathrm{O}_{3} / \mathrm{H}_{2} \mathrm{O}}$ are, respectively, equal to $0.8,0.8$ and 0.9 . The change in ozone content is about $10 \%$ per hour and the change in the vapor mixing ratio is $15 \%$ per hour. In this case, the two processes act on the ozone content variability. We estimate the chemical ozone production between 0 and $7 \mathrm{ppb} \mathrm{h}^{-1}$ according to the contribution of the turbulent transfer.

(c) Case number 27 (IOP 4) corresponds to a balloon that was launched from Martigues under Mistral conditions at 0900 UTC. The segment analyzed presents a strong correlation coefficient $R_{\mathrm{O}_{3} / \mathrm{H}_{2} \mathrm{O}}, r_{\mathrm{O}_{3}}$ and $r_{\mathrm{H}_{2} \mathrm{O}}$. The turbulent transport and chemical production seem to equally contribute to the variability because the percentage of variation is the same for water vapor mixing ratio and for ozone content (about 10\% per hour). The contribution of the chemical process can be estimated between 0 and $10 \mathrm{ppbh}^{-1}$ following the amount of contribution of the turbulent transfer.

(d) Case number 28 (IOP 4) corresponds to a balloon that was launched from Vallon Dol under a Mistral situation at 1000 UTC in the ABL. $r_{\mathrm{O}_{3}}$ equals to $0.97, r_{\mathrm{H}_{2} \mathrm{O}}$ to 0.56 and $R_{\mathrm{O}_{3} / \mathrm{H}_{2} \mathrm{O}}$ to 0.51 . However, the strong correlation $r_{\mathrm{O}_{3}}$ compared to the other correlation coefficients suggests that the chemical process is the predominant one, but can be affected by the turbulent transport.

In conclusion, we can consider that the major part of the variability of the ozone content measured by the constant volume balloons in the segments analyzed is due to chemical processes, except for four cases where the turbulent transport can play an important contribution.

\subsection{Chemical rates of ozone transformation}

The temporal evolution of ozone contents, presented in Table 3, suggests the following remarks:

- Constant volume balloon measurements take place between 0700 and 2000 UTC, with maximum frequency between 1000 and 1600 UTC. During this period, the ozone concentration can be expected to be the highest, and ozone formation can still be the predominant process in the ABL. Ozone concentration measured by balloons at heights between 600 and $900 \mathrm{~m}$ ranges from 36 to $100 \mathrm{ppb}$ (with a mean value of $63 \mathrm{ppb}$ ). In the SL layers that correspond to the free atmosphere above $\mathrm{ABL}$, ozone ranges from 40 to $85 \mathrm{ppb}$.

- The constant volume balloons launched from Martigues, to the northeast of the industrial area, flew under various meteorological conditions such as Mistral, westerly flow and sea breeze. The ozone concentrations measured by the balloons do not show any significant difference between the different large-scale atmospheric conditions despite the fact that the launching site is not exactly in the lee of the industrial plume during Mistral case. This may suggest that the ozone concentration is not clearly linked with primary industrial pollutants at local scale.

- Balloons launched from Vallon Dol, located to the north of the city of Marseille, flew inside the urban plume under sea breeze conditions. The maximum ozone under such meteorological conditions was observed near the ABL top (CVB13 25 June 2001 
Table 3

Characteristics of 28 CVB segments analyzed in this paper

\begin{tabular}{|c|c|c|c|c|c|c|c|c|c|c|c|c|c|}
\hline Case & IOP & Date & MT (UTC) & $\mathrm{LS}^{\mathrm{a}}$ & $\begin{array}{l}\text { FA } \\
(\mathrm{m})\end{array}$ & $\begin{array}{l}\text { BL- } \\
\text { type }\end{array}$ & $\begin{array}{l}\mathrm{O}_{3} \text {-variation } \\
(\mathrm{ppb})\end{array}$ & $\begin{array}{l}\mathrm{dO}_{3} / \mathrm{d} t \\
\left(\mathrm{ppb} \mathrm{h}^{-1}\right)\end{array}$ & $r_{\mathrm{O}_{3}}$ & $R_{\mathrm{O}_{3} / \mathrm{H}_{2} \mathrm{O}}$ & $\begin{array}{l}\mathrm{d} r / \mathrm{d} t \\
\left(\mathrm{~g} \mathrm{~kg}^{-1} \mathrm{~h}^{-1}\right)\end{array}$ & $r_{\mathrm{H}_{2} \mathrm{O}}$ & Remarks \\
\hline 1 & 0 & $\begin{array}{l}30 / 06 / \\
2000\end{array}$ & 1229-1421 & M & 750 & $\mathrm{ABL}$ & $48-76$ & 13 & 1 & 0.3 & -0.2 & 0.3 & $\begin{array}{l}\text { West synoptic } \\
\text { flow }\end{array}$ \\
\hline 2 & 0 & $\begin{array}{l}01 / 07 / \\
2000\end{array}$ & 0927-1024 & M & 800 & SL & $85-60$ & -20 & 0.9 & 0.2 & 0.2 & 0.1 & $\begin{array}{l}\text { Sea } \\
\text { breeze+Southerly } \\
\text { flow }\end{array}$ \\
\hline 3 & 1 & $\begin{array}{l}14 / 07 / \\
2001\end{array}$ & $1034-1432$ & M & 800 & $\mathrm{ABL}$ & $58-70$ & 3 & 1 & 0.3 & 0.2 & 0.3 & \\
\hline 4 & 1 & $\begin{array}{l}15 / 06 / \\
2001\end{array}$ & 0705-0800 & M & 700 & SL & $60-30$ & -18 & 0.9 & 0.9 & 1.1 & 0.5 & South west flow \\
\hline 5 & $2 \mathrm{a}$ & $\begin{array}{l}21 / 06 / \\
2001\end{array}$ & $1400-1600$ & M & 600 & $\mathrm{ABL}$ & $60-51$ & -5 & 0.7 & 0.8 & -0.2 & 0.4 & Mistral case \\
\hline 6 & $2 a$ & $\begin{array}{l}21 / 06 / \\
2001\end{array}$ & $1630-1700$ & M & 600 & SL & $73-71$ & -1 & 0.2 & 0.4 & -0.1 & 0.2 & \\
\hline 7 & $2 a$ & $\begin{array}{l}22 / 06 / \\
2001\end{array}$ & 0924-1016 & M & 600 & $\mathrm{ABL}$ & $60-64$ & 4 & 0.4 & -0.1 & -2.1 & 0.8 & Mistral case \\
\hline 8 & $2 b$ & $\begin{array}{l}24 / 06 / \\
2001\end{array}$ & $1118-1500$ & M & 600 & SL & 61 & 0 & 0.3 & 0.3 & 0.3 & 0.3 & Westerly flow \\
\hline 9 & $2 b$ & $\begin{array}{l}25 / 06 / \\
2001\end{array}$ & 0902-1026 & M & 650 & SL & 62 & 0 & 0.1 & 0.1 & -0.3 & 0.2 & Breeze case \\
\hline 10 & $2 b$ & $\begin{array}{l}25 / 06 / \\
2001\end{array}$ & $1048-1222$ & M & 650 & $\mathrm{ABL}$ & $64-70$ & 4 & 0.7 & 0.5 & -0.4 & 0.3 & \\
\hline 11 & $2 b$ & $\begin{array}{l}25 / 06 / \\
2001\end{array}$ & 1228-1305 & M & 650 & $\mathrm{ABL}$ & $70-74$ & 8 & 0.9 & 0.4 & 0.7 & 0.2 & \\
\hline 12 & $2 b$ & $\begin{array}{l}25 / 06 / \\
2001\end{array}$ & $1330-1430$ & VD & 900 & $\mathrm{ABL}$ & $90-100$ & 8 & 0.3 & 0 & 0.4 & 0.4 & Breeze case \\
\hline 13 & $2 b$ & $\begin{array}{l}25 / 06 / \\
2001\end{array}$ & $1512-1624$ & VD & 900 & SL & $72-67$ & -6 & 0.6 & 0 & -0.3 & 0.3 & \\
\hline 14 & $2 b$ & $\begin{array}{l}25 / 06 / \\
2001\end{array}$ & $1630-1700$ & VD & 900 & $\mathrm{ABL}$ & 94 & 0 & 0.1 & 0 & -2.6 & 0.5 & \\
\hline 15 & $2 b$ & $\begin{array}{l}26 / 06 / \\
2001\end{array}$ & 0831-0908 & VD & 850 & $\mathrm{ABL}$ & $46-48$ & 4 & 0.8 & -0.1 & 0.1 & 0.1 & Breeze case \\
\hline 16 & $2 b$ & $\begin{array}{l}26 / 06 / \\
2001\end{array}$ & 0908-1002 & VD & 850 & SL & $48-46$ & -2 & 0.8 & 0.1 & -0.2 & 0.2 & \\
\hline 17 & $2 b$ & $\begin{array}{l}26 / 06 / \\
2001\end{array}$ & $1002-1115$ & VD & 850 & SL & 47 & 0 & 0.6 & 0.2 & 0.6 & 0.7 & \\
\hline 18 & 3 & $\begin{array}{l}03 / 07 / \\
2001\end{array}$ & 1519-1600 & M & 600 & $\mathrm{ABL}$ & $60-69$ & 3 & 0.5 & 0.3 & 1.4 & 0.2 & Westerly flow \\
\hline 19 & 3 & $\begin{array}{l}04 / 07 / \\
2001\end{array}$ & 0930-1130 & VD & 600 & $\mathrm{ABL}$ & $65-75$ & 5 & 0.9 & -0.4 & -0.4 & 0.6 & Breeze case \\
\hline 20 & 3 & $\begin{array}{l}04 / 07 \mid \\
2001\end{array}$ & 1305-1419 & VD & 700 & $\mathrm{ABL}$ & $73-79$ & 5 & 0.3 & 0.1 & -0.2 & 0.1 & \\
\hline 21 & 3 & $\begin{array}{l}04 / 07 / \\
2001\end{array}$ & $1420-1538$ & VD & 700 & $\mathrm{ABL}$ & $79-75$ & -3 & 0.7 & -0.3 & 0.3 & 0.5 & \\
\hline 22 & 4 & $\begin{array}{l}10 / 07 / \\
2001\end{array}$ & $1418-1538$ & M & 800 & $\mathrm{ABL}$ & $69-77$ & 7 & 0.9 & 0.9 & 1.3 & 0.8 & Westerly flow \\
\hline 23 & 4 & $\begin{array}{l}10 / 07 / \\
2001\end{array}$ & $1540-1630$ & M & 800 & $\mathrm{ABL}$ & 60 & 0 & 0.4 & -0.2 & 1.1 & 0.7 & \\
\hline 24 & 4 & $\begin{array}{l}10 / 07 / \\
2001\end{array}$ & $1716-2013$ & M & 800 & $\mathrm{ABL}$ & $60-65$ & 2 & 0.4 & 0.3 & 0.1 & 0.3 & \\
\hline 25 & 4 & $\begin{array}{l}11 / 07 / \\
2001\end{array}$ & 1009-1035 & M & 700 & SL & $40-46$ & 10 & 0.9 & -0.3 & 0.4 & 0.3 & Mistral case \\
\hline 26 & 4 & $\begin{array}{l}11 / 07 / \\
2001\end{array}$ & 1058-1215 & M & 700 & $\mathrm{ABL}$ & $42-54$ & 8 & 1 & 0.1 & 0.1 & 0.2 & \\
\hline 27 & 4 & $\begin{array}{l}12 / 07 / \\
2001\end{array}$ & 0912-1004 & M & 600 & $\mathrm{ABL}$ & $42-57$ & 5 & 0.5 & -0.7 & -0.7 & 0.5 & Mistral case \\
\hline 28 & 4 & $\begin{array}{l}13 / 07 / \\
2001\end{array}$ & 1000-1149 & VD & 800 & $\mathrm{ABL}$ & $36-71$ & 7 & 1 & -0.6 & -0.5 & 0.6 & Mistral case \\
\hline
\end{tabular}

Number of case, IOP number (IOP), date (DATE), measurements time (MT), launching station (LS) (M: Martigues or VD: Vallon Dol), flight altitude (FA), type of the boundary layer (DATE) (BL-type) probed by the balloon (stable free atmosphere layer above ABL-SL- or inside the ABL), ozone content variation measured on every segment $\left(\mathrm{O}_{3}\right.$-variation), and values of its temporal variation $\left(\mathrm{dO}_{3} / \mathrm{d} t\right)$ in $\mathrm{ppb} \mathrm{h}^{-1}$, linear correlation coefficient for this trend $\left(r_{\mathrm{O}_{3}}\right)$. Last

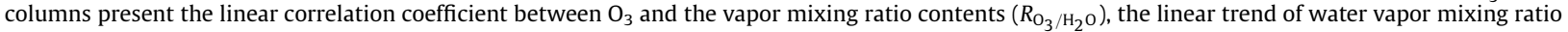
$(\mathrm{d} r / \mathrm{d} t)$ with its linear correlation coefficient $\left(r_{\mathrm{H}_{2} \mathrm{O}}\right)$, and the final column presents the type of meteorological situation.

a Martigues or VD: Vallon Dol. 
1330-1430 UTC) as seen also by aircraft measurements (Fig. 4b).

- Ozone temporal variation observed by balloons ranges from -20 to $13 \mathrm{ppbh}^{-1}$. During 16 cases ozone is produced, and the production rate is $>10 \mathrm{ppbh}^{-1}$ in only one case. In seven cases ozone is lost and the loss rate is lower than $-10 \mathrm{ppb} \mathrm{h}^{-1}$ in only two cases. In the five other cases the temporal variation of ozone content is insignificant. Mean ozone production rate is about $6 \mathrm{ppb} \mathrm{h}^{-1}$, and mean ozone lost rate is about $-8 \mathrm{pph} \mathrm{h}^{-1}$. Generally the strong negative values are observed near the pollutant sources and can be explained by a complex chemical process or by weak solar radiation at the end of the day.

- In the $19 \mathrm{ABL}$ cases, ozone production is the predominant process. Fifteen cases present a positive rate. Two exhibit a constant ozone content and two present a negative rate. In the nine SL observations made above ABL, five present ozone destruction. Three cases show near constant ozone concentrations and only one displays ozone production.

From this we can claim that: (i) net chemical production of ozone is observed in the upper part of the ABL and (ii) fresh pollutant precursors are probably transferred to the free atmosphere where chemical reactions for ozone occur. The latter result can be related to the works by Coll et al. (2005) based on aircraft measurements, which showed a strong chemistry activity above the ABL and particularly during IOP2b at $800 \mathrm{~m}$.

The case number 4 of 15 June 2001 between 0705 and 0800 UTC (Table 3)-for which the balloon flew above the $\mathrm{ABL}$ in a stable environment-is a case where turbulent transport could play a role in the ozone temporal variations. During this particular transect, the balloon flew over the industrial area of Martigues and one hypothesis could be that the industrial plumes may erode the ABL top and introduce fresh pollutants into this layer by turbulent transport that activated strong chemical reactions. These reactions have also been observed in the case of 1 July 2001 above ABL (case 2 of Table 3). Bastin and Drobinski (2005) found with numerical modelling that fresh pollutants can be introduced into the free atmosphere by upslope winds near the relief. The hills near the coast could create this kind of perturbation into the week ABL depth.

The ozone production rates deduced from the constant volume balloon quasi-Lagrangian measurements are comparable with results reported by Corsmeier et al. (2002), who found with a numerical evaluation that in the north lee of the city of Berlin the ozone-mixing ratio caused by precursor emissions presented a net chemical ozone production of $6.5 \mathrm{ppb} \mathrm{h}^{-1}$. The net ozone production corresponds to the local chemical terms (production or loss) describing a local change in the ozone-mixing ratio.

Balloon observations clearly show that ozone production is found mainly inside the convective ABL. Fig. 9 presents the values of the ozone temporal rate deduced from balloons' measurements against day hour (represented by the average time of every homogeneous path

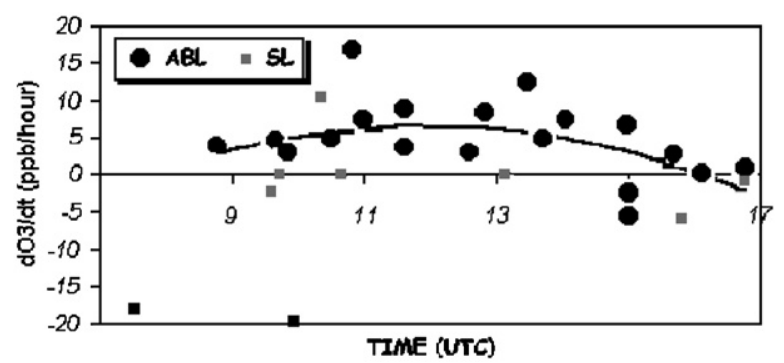

Fig. 9. Mean ozone production rates observed by the CVB balloons versus the mean path time within $\mathrm{ABL}$ and SL layers. The black line indicates the diurnal trend of ABL cases.

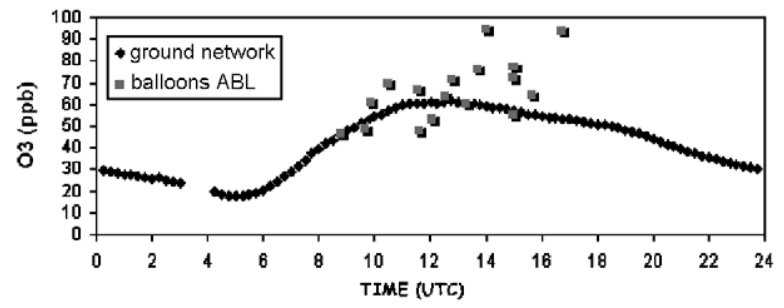

Fig. 10. Temporal evolution of mean ozone concentration measured by CVB balloons and diurnal cycle of the composite mean ozone content deduced from the ground network during the days of CVB flights.

measured, see Table 3). The negative values are found in the stable free atmosphere layers located above $\mathrm{ABL}$ during the morning (0800-1000 UTC) and during the evening for $A B L$ and the free atmosphere (SL cases after 1600 UTC). Between 1000 and 1600 UTC, the values observed inside the convective $\mathrm{ABL}$ are positive, reaching a maximum between 1200 and 1400 UTC, decreasing to negligible values near 1600 UTC. No large differences were found for the ozone rate between mistral and sea breeze conditions.

To better explain the measured ozone content trends, the diurnal cycle of the ozone content measured at ground level and the ozone content measured by the balloons near the top of the ABL are compared (Fig. 10). The ozone content at ground level is a composite mean diurnal cycle deduced from the ground measurements made by the AIRMAREX and AIRFOBEP networks, averaged for the same periods of the observations analyzed in Table 3.

The diurnal cycle observed at ground level presents a typical shape with a minimal concentration of $15 \mathrm{ppb}$ at 0500 UTC and a maximum of 55 ppb at 1200 UTC. Ozone concentration increases during the morning and starts to decrease very slowly after midday until 1800 UTC. The balloon-observed concentrations between 0800 and 1300 UTC are similar to surface-observed concentrations. Between 1300 and 1700 UTC, the ozone concentrations measured by the balloon are generally greater than mean surface concentrations. Fig. 10 indicates that balloon ozone measurements are made when the ozone concentration at surface level does not undergo major variations, which may explain the low ozone rates found near the top of the boundary layer by the balloon. After 1400 UTC the 
balloon ozone content appears higher than the mean value measured at surface level by the network. This may indicate that when ozone production runs out at ground level and destruction of ozone starts ozone production continues near the top of the boundary layer until 1800 UTC. This phenomenon may be due to the differences between the ground and the top of the boundary layer in solar radiation and in turbulent vertical transport of primary pollutants contents. The ozone present near the ABL top can stay in altitude during the night in the residual nocturnal layer as shown by Baumbach and Vogth (2003), who pointed out the important role played by the residual nocturnal layer (RL) which acts as a reservoir of ozone. The downward turbulent mixing produced in the morning is then responsible for a great part in the ozone concentration increase observed at the ground in cities.

\section{Conclusions}

In this paper, we present original results concerning quasi-Lagrangian measurements of ozone concentrations obtained with instruments, near the ABL top and in the stable layers of the free atmosphere just above the ABL. The balloon flight altitude has been systematically compared with the ABL top along its trajectory. Since a constant volume balloon flies almost at the same height (constant density levels), it can move from inside the ABL to above it in the stable free atmosphere or vice-versa. The vertical fluctuations of the balloon altitude, temperature and humidity measurements are good indexes of turbulence of the air masses probed by the balloon (outside of the lee waves regions), so that the position of the balloon relative to the $\mathrm{ABL}$ top could be determined.

To analyze the rate of time variation of the ozone content in the same layer, each flight is divided in several segments corresponding to either the unstable ABL or the stable free atmosphere above. For a balloon flying in the same air parcel, the ozone variability can be caused either by the chemical process or by the vertical turbulent mixing. The humidity content variations measured by the balloon are considered in a dry ABL to be only dependent on the surface latent heat fluxes and on the (turbulent) entrainment processes near the ABL top between ABL and free atmosphere. The correlation between ozone and humidity content has been calculated for each considered balloon trajectory segment. For most cases (22 cases over 28), the time variations of ozone content are not correlated with the time variations of vapor mixing ratio and the ozone production/destruction rates observed are mostly due to chemical processes. For only four cases, the contribution of the turbulent transport may play an important role.

In the free troposphere, ozone contents are almost constant or decrease. Ozone destruction rates for those situations can reach around $20 \mathrm{ppbh}^{-1}$. These results suggest that fresh pollutant emissions are introduced within the free atmosphere above ABL. Near the top of $\mathrm{ABL}$, the net production of ozone is observed at rates of about $6 \mathrm{ppbh}^{-1}$, which are similar to those found by
Corsmeier et al. (2002), deduced by numerical analysis of the ozone plume formed in the north lee of the city of Berlin. A maximum ozone production rate $13 \mathrm{ppb} \mathrm{h}^{-1}$ was found in those cases. Morning ozone concentrations measured at the ABL top by balloons are similar to that observed by the ground network, but after midday, and particularly from 1400 UTC onward, the ozone content measured with the constant volume balloons appears higher than measurements at surface level. The process continues near the top of boundary layer until 1800 UTC. This phenomenon may be due to the differences in solar radiation and in the turbulent vertical transport process of primary pollutants between the ground and the top of the boundary layer.

\section{References}

Baumbach, G., Vogth, U., 2003. Influence of inversion layers on the distribution of air pollutants in urban areas. Water, Air and Soil Pollution: Focus 3, 65-76.

Bastin, S., Drobinski, P., 2005. Sea breeze induced mass transport over complex terrain in southeastern France: a case study. Quarterly Journal of the Royal Meteorological Society 132, 405-423.

Beekman, M., Ancellet, G., Martin, D., Abonnel, C., Duverrneuil, G., Eideliman, F., Bessemoulin, P., Fritz, N., Gizard, E., 1995. Intercomparison of tropospheric ozone profile obtained by electrochemical sondes, a ground based lidar and an airborne UV photometer. Atmospheric Environment 29 (9), 1027-1042.

Borrego, C., Countinho, M., Barros, N., 1994. Atmospheric pollution in the Lisbon Airshed. In: Power, H., Moussiopoulos, N., Brebbia, C.A. (Eds.), Urban Air Pollution. Computational Mechanics Publications, Southampton, UK.

Borrell, P., Builtjes, P., Grennfelt, P., Hov Van Aalst, R., Fowler, D., Megie G., Moussiopoulos, N., Warneck, P., Volz-Thomas, A., Wayne, R., 1995. Photo-oxidants, Acidification and Tools: Policy Applications of EUROTRAC Results. EUROTRAC ISS, Garmisch-Partenkirchen, Germany.

Ciccioli, P., Brancaleoni, E., Di Paolo, C., Brachetti, A., Cecinato, A., 1987. Daily trends of photochemical oxidants and their precursors in a suburban forested area: a useful approach for evaluating the relative contributions of natural and anthropogenic hydrocarbons to the photochemical smog formation in rural areas of Italy. In: Angeletti, G., Restelli, G. (Eds.), Physico-Chemical Behavior of Atmospheric Pollutants, Proceedings of the Fourth European Symposium. D. Reidel Publishing Co., Dordrecht, Netherlands.

Coll, I., Pinceloup, S., Perrros, P.E., Leverdet, G., Le Bras, G., 2005. 3D analysis of high ozone production rates observed during the ESCOMPTE campaign. Atmospheric Research 74, 477-505.

Corsmeier, U., Kalthtoff, N., Vogel, B., Hammer, M.U., Fielder, F., Kottmeier, C.H., Volz-Thomas, A., Konrad, S., Glaser, K., Neininger, B., Lehning, M., Jaeschke, W., Memmersheimer, M., Rappenglück, B., Jakobi, G., 2002. Ozone and PAN formation inside and outside of the Berlin plume: process analysis and numerical process simulation. Journal of Atmospheric Chemistry 42, 289-321.

Cros, B., Durand, P., Cachier, H., Drobinski, Ph., Frejafon, E., Kottmeier, C., Perros, P.E., Peuch, V.H., Ponche, J.L., Robin, D., Saïd, F., Toupance, G., Wortham, H., 2004. The ESCOMPTE program: an overview. Atmospheric Research 69 (3\&4), 241-279.

Davies, T.D., Schuepbach, E., 1994. Episodes of high ozone concentrations at the earth's surface resulting from transport down from the upper troposphere/lower stratosphere: a review and case studies. Atmospheric Environment 28 (1), 53-68.

Drobinski, P., Saïd, F., Ancellet, G., Arteta, J., Augustin, P., Bastin, S., Brut, A., Caccia, J.L., Campistron, B., Cautenet, S., Colette, A., Cros, B., Corsmeier, U., Coll, I., Dabas, A., Delbarre, H., 2005. Regional transport and dilution during high pollution episodes in southeastern France: summary and findings from the Field Experiment to Constraint Models of Atmospheric Pollution and Emissions Transport (ESCOMPTE). Journal of Geophysical Research 112, D13105.

Fortezza, F., Strocchi, V., Giovanelli, G., Bonasoni, P., Georgiadis, T., 1993 Transport of photochemical oxidants along the northwestern adriatic coast. Atmospheric Environment 27A, 2393-2402.

Frejafon, E., Abonnel, C., Allet, C., Ancellet, G., Bénech, B., Durand, P. Gizard, E., Godet, Y., Junkermann, W., Kottmejer, C., Menard, T., 
Perros, P., Saïd, F., 2002. Quality control of altitude ozone measurements and database optimization during the ESCOMPTE campaign. In: XXVII General Assembly of the European Geophysical Society, 21-26 April 2002. Nice, France.

Georgiadis, T., Giovanelli, G., Fortezza, F., 1994. Vertical layering of photochemical ozone during land-sea breeze transport. Nuovo Cimento 17, 371-375.

Guénard, V., Drobinski, P., Caccia, J.L., Campistron, B., Vence, B., 2005. Observational study of the mistral mesoscale dynamics. Boundary Layer Meteorology 115 (2), 263-288.

Hastie, D.R., Narayan, J., Schiller, C., Niké, H., Shepson, P.B., Sills, D.M.L., Taylor, P.A., Moroz, W.J., Drummond, J.W., Reid, N., Taylor, R., Russel, P.B., Melo, O.T., 1999. Observational evidence for the impact of the lake breeze circulations on ozone concentrations in southern Ontario. Atmospheric Environment 33, 323-335.

Kalthoff, N., Kottmeier, C., Thürauf, J., Corsmeier, U., Saïd, F., Fréjafon, E., Perros, P.E., 2005. Mesoscale circulation systems and ozone concentrations during ESCOMPTE: a case study from IOP 2b. Atmospheric Research 74, 335-380.

Koffi, E., Georgelin, G., Benech, B., Richard, E., 2000. Trapped lee waves observed during PYREX by constant volume balloons: comparison with meso-NH simulations. Journal of the Atmospheric Sciences 57 (130), 2007-2021.

Millan, M.M., 1993. Photo-oxidation in the mediterranean region: relevant atmospheric processes. In: Borrell, P.M. (Ed.), The Proceedings of EUROTRAC Symposium '92, SPB. Academic Publishing, The Hague, Netherlands.
Millan, M.M., Artano, B., Alonso, L., Castro, M., Fernandez-Patier, R., Goberna, J., 1992. Meso-meteorological Cycles of Air Pollution in the Iberian Peninsula (MECAPIP). Air Pollution Research Report 44, European Commission, DG XII/E-1, Brussels, Belgium.

Millan, M.M., Salvador, M.R., Mantilla, E., Artinano, B., 1996. Meteorology and photochemical air pollution in southern Europe: experimental results from EC research projects. Atmospheric Environment 30 (12), 1909-1924.

Moussiopoulos, N., 1994. Air pollution in Athens. In: Power, H., Moussiopoulos, N., Brebbia, C.A. (Eds.), Urban Air Pollution. Computational Mechanics Publications, Southampton, UK.

Rosenthal, J.S., Helvey, R.A., Bettalino, T.E., Fisk, C., Greiman, P.W., 2003. Ozone transport by mesoscale and diurnal wind circulations across southern California. Atmospheric Environment 37, 51-71.

Saïd, F., Brut, A., Campistron, B., Cousin, F., 2007. Investigation of the atmospheric boundary layer dynamics during ESCOMPTE campaign. Annals of Geophysics 25, 597-622.

Stull, R.B., 1993. An Introduction to Boundary Layer Meteorology. Kluwer Academic Publisher, Dordrecht, pp. 10-11.

Volz, A., Kley, D., 1988. Evaluation of the Montsouris series of ozone measurements made in nineteenth century. Nature 332, 240-242.

Ziomas, I.C., Gryning, S.-E., Borstein, R.D. (Eds.) 1998. The Mediterranean Campaign of Photochemical Tracers-Transport and Chemical Evolution (MEDCAPHOT-TRACE): Athens, Greece 1994-1995. Atmosheric Environment, 32 (12), 2043-2326. 